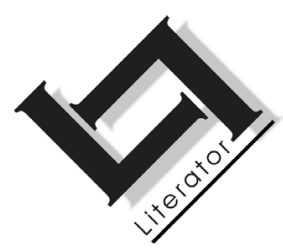

\title{
Plotting the lyric: forms of narration in poetry ${ }^{1}$
}

\author{
P. Hühn
}

University of Hamburg

HAMBURG

Germany

E-mail: huehn@uni-hamburg.de

\section{Abstract}

\section{Plotting the lyric: forms of narration in poetry}

This article is based on the assumption that lyric poems generally share the fundamental constituents of story and discourse as well as the narrative act with narrative fiction in that they likewise feature a sequence of incidents (usually of a mental kind), mediate and shape it from a specific perspective and present it from a particular point of time vis-à-vis the sequence of incidents. A general outline of the narratological categories which may be applied to poetry analysis is given using William Wordsworth's "I wandered lonely as a cloud" as an illustrative example. The aim of the article is heuristic: the intention is not to blur the distinction between fiction and poetry and treat poems indiscriminately as narrative texts, but rather identify and highlight the specifically poetic forms and functions which instances of narrating adopt in poems. The main section of the article will then focus on the first of the three aspects mentioned, the modelling of poetic sequentiality, i.e. the specification of types of plot, plotting and presentation of plot in poetry and the analysis of their functions.

1 This article has been published in:

MÜLLER-ZETTELMAN, E. \& RUBIK, M., eds. 2005. Theory in poetry: new approaches to the lyric. Amsterdam: Rodopi. p. 147-172. 


\section{Opsomming}

\section{Die liriese intrige: manifestasies van narratiwiteit in die poësie}

Hierdie artikel is gebaseer op die aanname dat liriese gedigte en verhalende tekste die fundamentele samestellende elemente van storie en verhaal, asook die vertelhandeling in gemeen het. Die rede hiervoor is dat albei soorte tekste bestaan uit 'n reeks gebeurtenisse (meestal van 'n mentale innerlike aard), wat gemedieër en gestruktureer word vanuit 'n bepaalde perspektief en gerepresenteer word vanuit ' $n$ bepaalde moment in tyd teenoor die reeks gebeurtenisse as sodanig. 'n Oorsig van die narratologiese kategorieë wat toegepas kan word in die analise van die poësie word verskaf. "I wandered lonely as a cloud" van William Wordsworth word as voorbeeld gebruik. Die doel van die artikel is heuristies. Die intensie is nie om die onderskeid tusssen verhaal en gedig te vertroebel nie en ook nie om gedigte op onoordeelkundige wyse as verhalende tekste te behandel nie. Die doel is eerder om die spesifiek poëtiese vorms en funksies wat verhale en vertelling in gedig kan aanneem, te identifiseer en te beklemtoon. In die sentrale gedeelte van die artikel sal gefokus word op die drie reeds genoemde aspekte van narratiwiteit in gedigte, naamlik die strukturering van poëtiese opeenvolging (d.w.s. die spesifisering van bepaalde soorte "plot"), die verhaalmatige omvorming van die storiegegewens en die representasie van die verhaal (d.w.s. van die estetiese omvormde storiemateriaal) in gedigte en die analise van die funksies van hierdie drie aspekte in die poësie.

\section{Mapping narratology onto poetry}

The theoretical foundations of poetry criticism are increasingly being deplored as deficient. On the one hand, attempts at a conclusive definition of poetry as a genre after the model of narrative fiction or drama have failed (cf. Warning, 1997:17 ff.). On the other hand, the analytical categories and procedures of poetry interpretation have been criticised as largely intuitive, eclectic and lacking systematic organisation. As has recently been suggested (cf. Müller-Zettelmann, 2000; 2002; Hühn, 2002; Hühn \& Schönert, 2002), this unsatisfactory state of poetry criticism may be remedied by drawing on the theoretical and methodological achievements of narratology as the elaborate theory and analytic methodology of narrativity. This is arguably the most complex and universal verbal (and, moreover, generally semiotic) mode of structuring, interpreting and representing experience and making sense of the world (Bruner, 1990; Fludernik, 1996; Wolf, 2002). This most complex mode of communication may be mapped onto the traditional genres as a means of specifically 
highlighting their distinctive features. As for poetry, such a transgeneric recourse to narratology is apt to demonstrate that narrative texts and lyric poems, in spite of their apparent differences in form, technique and function, share essential constituents and that narratological categories can, therefore, profitably be applied to poetry in the expectation that the more comprehensive scope and highly developed status of narratology as well as the discriminatory capacity of narratological terminology will both offer a fresh impetus to the theory of poetry and suggest new practical methods for the analysis of poems. ${ }^{2}$

The majority of narratological models explicitly or implicitly rest on the premise that narrativity is constituted by the combination and interaction of two different dimensions, of sequentiality and mediacy: a sequence of incidents (together with existents such as figures and setting) evolving in time, on the one hand (termed "histoire" by Genette, "story" by Chatman) and, on the other, the structured representation and communication of such a sequence by a mediator in a semiotic medium and from a particular position (Genette's "récit", Chatman's "discourse"). ${ }^{3}$ It has to be emphasised from the outset

2 The argument pursued in this article is based on the work of the project group P6 "Narratological Poetry Analysis", conducted by Jörg Schönert and the author $(\mathrm{PH})$, as part of the Research Group "Narratologie" funded by DFG at Hamburg University from 2001 to 2004. See Hühn and Schönert (2002), whose argument the present article seeks to expand and develop further with respect to the dimension of sequentiality.

3 For the pervasiveness of this distinction among narratologists, see e.g. Martin (1986:81 ff., 107 ff.), Martinez and Scheffel (1999:20 ff.) and Herman (2002:13, $211 \mathrm{ff}$.). Various other oppositions - with partly differing definitions - have been proposed for this basic distinction, such as "fabula" versus "sjužet" (the Russian formalists, esp. Tomaševskij, 1965), "histoire" versus "discours" (Todorov, 1966) or "story" versus "text" (Rimmon-Kenan, 2002). Numerous influential narratologists, however, tend to concentrate on only one of these two dimensions: Stanzel (1979), Genette (1980), Rimmon-Kenan (2002) mainly on the discourse level and the forms and modalities of mediacy (with the further differentiation, for instance, between voice and focalisation); Propp (1968), Bremond (1973), Frye (1957) on the story-dimension and the modalities of plot-development. This premise has been categorically rejected by Fludernik (1996), who grounds her narratological concept prototypically in the everyday situation of oral storytelling and the conversational communication of personal real life experiences, equating narrativity with what she calls experientiality and consciousness. Such an approach does not readily lend itself to the transgeneric application of narrative theory to develop new categories and terms for poetry analysis. Moreover, her narrow notion of embodiedness excludes all poems from the potential range of "natural" narratology which do not imply the situational and personal specification of the speaker's voice (as a quasireal individual person). 
that positing such a double constitution of narrativity does not at all presuppose the objective or ontological existence of story in a factual or fictional world prior to, and independent of, its transformation into discourse. Instead, the relation between story and discourse has to be construed as mutually dependent: discourse presupposes story, and story is constituted only by discourse (Culler, 1981), a dialectical relationship which one may describe in either of two directions: analytically or genetically. To these two, a third dimension has to be added: the narrative act (Genette's "narration"), the act of utterance (speaking or writing) through which the incidents and existents (on the story level) are transformed into the discourse level.

This article is based on the assumption that lyric poems generally share the fundamental constituents of story and discourse 4 as well as the narrative act with narrative fiction in that they likewise feature a sequence of incidents (usually of a mental kind), mediate and shape it from a specific perspective 5 and present it from a particular point of time vis-à-vis the sequence of incidents. Firstly, a general outline will be given of the narratological categories which may be applied to poetry analysis using William Wordsworth's "I wandered lonely as a cloud" as an illustrative example. My aim is heuristic: I do not intend to blur the distinction between fiction and poetry and treat poems indiscriminately as narrative texts. The aim is rather to identify and highlight the specifically poetic forms and functions which instances of narrating adopt in poems. The main section of the article will then focus on the first of the three aspects mentioned, the modelling of poetic sequentiality, i.e. the specification of types of plot, plotting and presentation of plot in poetry and the analysis of their functions.

4 The analytical terminology used in the present article is mainly drawn from the narratological models of Chatman (1978): story and discourse, existents, and Genette (1980), Rimmon-Kenan (2002): focalisation, diegesis with the distinction between the two scales of participation and mediation, namely homo/ auto/heterodiegetic and extra/intra/hypo/hypohypodiegetic. In cases where new terms are introduced (sequence, event, subject of composition, plot, frame, script), these will briefly be explicated.

5 So far, only narrative (and epic) poetry has been subjected to narratological analysis, e.g. by Kinney (1992) and Grossman (1998). The present article, however, deliberately goes beyond such attempts by suggesting the fruitfulness of applying narratological categories especially to non-narrative verse, to lyric poetry in the narrow sense of the term. For first attempts in this direction, see Hühn (2002) and Müller-Zettelmann (2002). 


\section{I wandered lonely as a cloud}

1 I wandered lonely as a cloud

2 That floats on high o'er vales and hills,

3 When all at once I saw a crowd,

4 A host, of golden daffodils;

5 Beside the lake, beneath the trees,

6 Fluttering and dancing in the breeze.

7 Continuous as the stars that shine

8 And twinkle on the milky way,

9 They stretched in never-ending line

10 Along the margin of a bay;

11 Ten thousand I saw at a glance,

12 Tossing their heads in sprightly dance.

13 The waves beside them danced; but they

14 Out-did the sparkling waves in glee:

15 A poet could not but be gay,

16 In such a jocund company:

17 I gazed - and gazed - but little thought

18 What wealth the show to me had brought:

19 For oft, when on my couch I lie

20 In vacant or in pensive mood,

21 They flash upon the inward eye

22 Which is the bliss of solitude;

23 And then my heart with pleasure fills,

24 And dances with the daffodils.

(De Selincourt, 1944:2167.)

\section{The dimension of sequentiality in poetry}

Narratological concepts can be employed for a more differentiated analysis of the sequence of incidents in poems than hitherto possible by explicitly specifying the techniques applied for creating a coherent causal, temporal or otherwise "motivated" syntagmatic string - what may be called a poetic plot. Plots in poetry are typically constituted by mental or psychological incidents such as perceptions, imaginations, desires, anxieties, recollections or emotions and their emergence and development. I will suggest a general model of plot description (applicable to plots both in narrative fiction and in poetry) drawing on concepts from cognitive psychology and linguistics, particularly the notion that it is only through the paradigmatic reference to world knowledge, to schemata familiar from general experience or literature (i.e. culturally specific or intertextual contexts and patterns which are already meaningful) that individual incidents and existents 
in texts can be selected, grouped and transformed into a coherent narrative sequence or plot and thus endowed with meaning. 6

Two types of such schemata are to be distinguished: frames (thematic or situational contexts, such as death, sea travel or sexual love) and scripts (sequence patterns, i.e. established, conventional procedures or stereotyped processes, such as the process of bodily deterioration in dying, the regulated departure of a ship from a harbour for an ocean voyage, or to take a literary example, the formalised ritual of courtly love). Whereas the activation of frames enables the reader to connect various elements in different parts of the text and interpret a poem (like any other text) in terms of its situational or thematic significance and coherence in a primarily static respect, referring the sequence of the elements to one or more scripts within such a frame presents a specific means of modelling the dynamic, i.e. particularly narrative dimension of the text. On account of their brevity as well as the conventional tendency to situational abstractness and generality (cf. Müller-Zettelmann, 2000:73-83), poems are typically less explicit and circumstantial in the presentation of textual signals for the activation of frames and scripts and therefore require the reader more extensively than in novels to infer the relevant schemata from implicit indications. This is also the reason why narrative sequences in poems normally do not reach the degree of concrete circumstantiality and detailed elaboration possible and usual in novels.

In Wordsworth's "I wandered lonely as a cloud", frame and script activated by the text can be identified on two levels and in two respects. On a concrete and more general level, the frame has to be understood as walking and enjoying wild extrahuman nature as a vital environment for the individual's sense of living, and the script as seeking meaningful vitalising experiences in nature. In a more specific, namely poetological respect, the poem read in the context of romantic reflections on art and especially of Wordsworth's own artistic concepts (in the "Preface" to Lyrical ballads) can be seen to imply the thematic frame of poetic creativity and the power of imagination

6 Semino (1995) applies schemata to poems without, however, using the concept of narrativity. See also Culler (1975:139-160), Herman (1997) and Herman, (2002:85-113), as well as, especially for the concept of the frame, Goffman (1974). For a different approach, see Wolf (2002:46-51), who specifies what he calls the "syntactical narreme" in formal terms such as chronology, teleology, causality and thematic coherence. 
and as its script the process of poetic creation proceeding from "emotion recollected in tranquillity".

Another type of paradigmatic relations, i.e. equivalences among textual elements, is established by isotopies (Greimas, 1966), i.e. semantic features or aspects ("semes") recurring in a number of lexical units throughout a poem, thus creating new connections within its text and conferring additional layers of meaning on its sequence. In Wordsworth's poem, four such isotopies occur. First, the anthropomorphic or human aspect in the presentation of the daffodils ("crowd", "host", "dancing", "heads", "sprightly", "dance", "out-did", "glee", "jocund company", I. 3-16). Second, the social feature indicated in the polarity of loneliness and communality, with respect both to the speaker and the daffodils as well as to their relationship (see "l" / "lonely", "on high o'er", "crowd" / "host", "ten thousand", "their heads", "company", "dances with the daffodils", I. 1-24), stressing the joy of being in company. Third, the high value attached to the flowers, and by extension, to their company ("golden", "wealth", I. 4, 18 ), and, finally, the visionary or transcendent quality of perception and recollection ("sparkling", "flash" / "inward eye", I. 14, 21). Through these isotopies, the structure of the sequence and its significance can be interpreted in social psychological terms as a development from (unacknowledged) painful isolation and loneliness to communal integration as a source of happiness and joy. This experience of spontaneously and emotionally becoming part of nature is presented as supplanting in its personal relevance human relationships, taking the place of human society and social values.

Furthermore, the term event will be used to designate the "point", as it were, of the narrative, that which makes it worth telling. Eventfulness can be defined with reference to the degree of deviation from the expected continuation of the sequence pattern activated by the text (cf. Lotman, 1972:329 ff.: "transgression of boundaries"; Bruner, 1991:11-13: "canonicity and breach"). Since sequences can deviate from expectations to a greater or lesser degree, eventfulness has to be conceived of as gradational. In "I wandered lonely as a cloud", the syntagmatic and paradigmatic organisation transforms the sequence into a plot with its own eventfulness in two stages of decisive change, through a shift (first) in focus and (second) in temporality. In line 15 the focus shifts from the description of the perceived (the flowers) to the perceiver and his reaction: spontaneous gaiety (I. 15) and lack of reflection ("I gazed - and gazed - but little thought [...]", I. 17). A more decisive shift, for which the first change serves as a preparation, occurs directly afterwards, at the beginning of the last 
stanza: from immediate perception to delayed recollection, from the present experience to the imaginative representation of past experience, from unreflective spontaneity to selfconscious awareness ("[l] little thought / What wealth the show to me had brought: / For [...]", I. $17 \mathrm{ff}$.). Both changes signal the experience of joy and communality ("jocund company", I. 16; "dances with the daffodils", I. 24) against the background of loneliness and emptiness ("wandered lonely", I 1; "in vacant or in pensive mood", I. 20). The event, which thus is realised in two successive stages, consists in the sudden transition from the unreflected singular experience (told in the past tense) to the repeated and indefinitely repeatable ("oft", I. 19) renewal of this joyful experience through recollection and imagination (told in the present tense), i.e. the potentially permanent resolution of the problem of isolation and lack. One important quality of this eventful recollection is its suddenness and unexpectedness ("flash", I. 21). Thus, the event is here defined by its surprise effect, its unpredictability.

The highest - macro-structural - organisation on the discourse level of a narrative text and also a poem will be called the plot. A plot is the result of the selection, weighting and correlation of meaningful sequences as well as the combination and integration of schemata and equivalences, usually ascribed to an agent and structured through this reference. Events form the crucial (turning) points in the development of plots and are in turn defined by these. In poetry, plots typically refer to ideas, memories, desires, emotions, imaginations and attitudes which the agent in a monological reflective and cognitive process ascribes to himself as his plot. The plot of Wordsworth's "I wandered lonely as a cloud" is constituted by the speaker's specific experience of nature as the source of joy and inspiration and the later imaginative reproduction of this experience through which its vitalising and integrating power is reactivated and thus preserved in the mind as well as (ultimately) in the very text of this poem. By ascribing this narrative of a vitalising experience and its imaginative recreation to himself the speaker identifies himself as a creative poet. That this narrative of poetic creativity as well as its self-attribution remain largely implicit has to be interpreted as significant. The act of artistic creation is always precarious (because it is self-induced) and must not be observed too closely (see below). 


\section{Dimensions of mediacy in poetry}

\subsection{Agents of mediacy}

This description of the syntagmatic and paradigmatic organisation of poems in terms of narrative sequences has to be supplemented by a specification of the forms and levels of poetic mediacy through which these operations are performed, or more precisely, to which they are attributable. There are two basic dimensions of mediacy. One concerns the four levels and agents of mediation, namely the biographical author; the compositional organisation of the text, which can be called the subject of composition or the textual subject; the speaker or narrator; and the protagonist (i.e. the main figure featured in the incidents narrated). In this context, the reference to the empirical author is relevant merely as a criterion for determining the historical (and cultural) plausibility of possible frames and scripts. The subject of composition (a structural redefinition of what formerly was called the "implied author") is the construct to which the norms inherent in the stylistic, rhetorical and tropical organisation of the poetic text are attributable and which may function as a means of backgrounding or foregrounding the speaker's stance. ${ }^{7}$ For the reader, this level constitutes a superior vantage point above the speaker's position from which the latter's "blind spots", and in general, his personal (partly unconscious) predispositions and limitations can be observed (Hühn, 1998). Ultimately, the distinction between the levels of subject of composition and personalised speaker is dependent on interpretation and has to be determined on the basis of attribution.

In Wordsworth's "I wandered lonely as a cloud", the particular composition of the text permits the reader to see not only the speaker's personal anxieties and desires, but also the specifically self-induced process of creation which, as indicated above, must be hidden from

7 The concept of the implied author has been severely criticised for its vagueness, inconsistency, indeterminacy between structure and intentionality, insufficiently defined theoretical status, et cetera (Bal, 1981; Nünning, 1993; Kindt \& Müller, 1999). To avoid these associations, the term is here replaced by "subject of composition" or "textual subject". The concept is redefined as a structural perspective, which does serve a useful and indeed indispensable interpretative function. It has to be emphasised that the subject of composition functions less as a positive norm (it has no voice) than "negatively". This is implied through the perceived discrepancies between the structure of the text and the propositional content of the utterance, i.e. through textual inconsistencies and contradictions (cf. Nünning, 1999:64-65). 
self-observation, i.e. be preserved as a "blind spot". These two aspects of the speaker's blind spots are largely revealed through the metaphors and attributes used (i.e. the isotopies, see above), beneath his level of consciousness - betraying, on the one hand, his suffering from isolation and loneliness ("lonely as a cloud", "on high o'er [...]", "on my couch", "solitude") and, on the other, his longing for a community, which manifests itself both in the anthropomorphisation of the flowers (e.g. "dancing", "heads", etc.) and the circumscription of their mass in the terms of human company ("crowd", "host", "sprightly dance", "jocund company", "dances with the daffodils"). What the text of the poem thus reveals behind the speaker's back, as it were, is the self-induced process of creation, namely that the speaker unwittingly first projects human meaning and value onto the non-human elements in nature and then extracts them again to stabilise and revitalise himself, thereby effecting his imaginative integration in a larger organic entity.

\subsection{Types of perspectives}

The other dimension of mediacy concerns the different types of perspective, namely the distinction between voice and focalisation, between the agent to whom the language used, the verbal utterance, is ascribed ("who speaks?") and that to whom the perception and cognition are attributed, i.e. the deictic centre whose perceptual as well as cognitive, psychological and ideological focus on the events is conveyed ("who perceives?"). Voice and focalisation can coincide in poetry as in fiction, but they can also be distinct, in homo- or autodiegetic narration typically as the subtle difference between the narrating and the experiencing (perceiving or reflecting) self, a difference in temporal as well as cognitive and emotional terms. For the analysis of both dimensions of mediacy, Genette's (1980) approach and terminology as modified and supplemented by Bal (1985), Rimmon-Kenan (2002), Chatman (1990) and Jahn (1996) provide a viable basis (cf. also Fludernik, 2001).

These two sets of differential categories can be utilised for a more systematic differentiation and analysis of the levels and forms of mediation and perspectivisation than are normally distinguished within lyrical texts. What can thus be elucidated more precisely are such specifically lyrical phenomena as the suggested collapse or the emphatic separation of levels of mediation. Romantic poems, for example, often suggest the identity of narrator (speaker) and protagonist as well as the coincidence of voice and focalisation through simultaneous narration, the use of the present tense and first-person 
pronouns (cf. Wolf, 1998). This, however, has to be interpreted as a contrived effect designed to hide the manipulation and deliberate organisation of a particular story and create the illusion of immediacy, spontaneity and thus authenticity. 8 In its first three stanzas Wordsworth's poem indicates the distance between the speaker's retrospective narrative stance, his voice (the use of the past tense) and his simultaneous focalisation, simultaneous, that is, with the past experience, during which he did not reflect on its significance for himself as made explicit at the end: "but little thought". In the last stanza, voice and focalisation coincide in the form of simultaneous narration, suggesting the present, immediate enactment of what is being described (the use of the present tense). It is only in the introductory phrase to the rendering of this enactment that the mediated quality is marked ("For oft [...]", I. 19), which in the rest of the stanza, however, is backgrounded, suggesting immediacy, authenticity and permanence.

Finally, one central aspect of the narrative set-up of a poem (as of any text) is the precise (temporal) location of the act of narration with respect to the progression of the plot, whether it is prospective, simultaneous or retrospective, et cetera, and in close connection with this, the function of the act of narration for the speaker. Wordsworth's speaker, in "I wandered lonely as a cloud", combines retrospective with simultaneous acts of narration. The decisive eventful change occurs exactly at the point of transition from retrospectivity (in the past tense) to simultaneity of narration (in the present tense), namely between lines 18 and 19, between the third and fourth stanzas, i. e. the unexpected change - the sudden re-creation of the speaker's imaginative participation in the vitality and joy of nature, is being performed, as it were, at the same time as the act of reading (and, moreover, can be repeated - also like the act of reading). The function of narration may then be described, with respect to the diegetic level, as the telling as well as the practical enactment of the

For the analysis of the analogous phenomenon in prose fiction, see Nünning (2001). The forms and functions of dramatising the act of narration through staging a "storytelling scenario" and creating the illusion of an ongoing process at the extradiegetic level ("mimesis of narration"), which may be elaborated to such an extent that the text in fact presents (narrates) the unfolding story of narrating the story. See the term Erzählgeschichte (story of narration) proposed by Schmid (1982:95). Nünning (2001:32-35) introduces the term metanarration to distinguish this phenomenon from "metafiction", the thematisation of the fictionality of the narrated story. 
act of imaginative (re)creation and, with respect to the extradiegetic level, as the speaker's self-identification as a poet.

\section{Forms of plot and plotting in poetry}

Plot represents the highest principle of imposing semantic order and coherence on the poem and the world mediated through it (see e.g. Ronen, 1990:823). Although plots and their events normally refer to, and are located on the story level ("story events"), they are always constituted by the discourse level in the first place, since plots and events have no existence in the (factual or fictive) world. However, as will be shown, reference and location may be shifted entirely to the discourse level ("discourse events"), where the medium as such is thematised and takes over plot function. In general, lyric plots can be described and categorised in the following respects: 9 type (thematic frame of development), structure (dynamic impulse and plot mechanism), protagonist (homo- and autodiegetic or heterodiegetic relation between narrator and protagonist), act of narration (temporal relation to the development of the narrative), function (esp. for narrator), eventfulness (type of event and location on story or discourse level). ${ }^{10}$ I will now analyse the forms and mechanisms of emplotment in a small number of illustrative poems ${ }^{11}$ exemplifying both basic varieties, story events and discourse events. For the heuristic purpose of this article, the primary focus will be on two central aspects of the plot structure in poems, the varying temporal position

Weststeijn (1989) provides an early approach to the description of what he calls "lyric sujet" mainly pointing out the specifically poetic features of plot, namely the tendencies to generality, the reduction of circumstantiality and the preference for mental developments. For a tentative application of the plot concept to the analysis of Romantic poetry, see Stillinger (1985).

For narrative fiction various systems of plot classification have been suggested (See e.g. Friedman, 1967 and Ryan, 1991). Friedman classifies plots of fortune, character and thought (with further subcategories), thus distinguishing changes with respect to the protagonist's situation, personality and consciousness. Ryan (1991) uses possible-world concepts (e.g. the character's domain subdivided into knowledge, wish, obligation and intention worlds as well as authentic and pretended worlds) to define a typology of narrative conflicts as a basis for plot types. Both approaches offer means of describing plot mechanisms in poems as well, although the tendency in poetry to reducing the concrete circumstantiality of situations make it less readily applicable here. Therefore, additional categories would have to be developed to suit the specific situation in poetry.

11 Since these poems serve as illustrative examples of a heuristic application of narratological categories to poetry analysis, I have refrained from discussing existing critical studies of these texts. 
of the act of narration within the narrative sequence, and the particular function of plotting and narration for the narrator. Within each category, simple and more complex instances of plotting will be contrasted. All examples selected feature homo- or autodiegetic (instead of heterodiegetic) narrators, since such a constellation makes for a wider spectrum of possible functions of narration.

\subsection{Story events: retrospective narration}

The plot of Wordsworth's "I wandered lonely as a cloud" can be defined, as mentioned above, by two thematic frames - first, in a general respect, the vitalising experience of joy in nature and its subsequent repetition through recollection; second, in a specifically poetological respect, the recreation of the vitalising experience in a spontaneous act of poetic imagination. The plot development derives its dynamic force from the (repeated) succession of lack and fulfilment. The speaker's initial condition is marked by loneliness and isolation ("lonely", "on high o'er", I. 1-2), which is then remedied through the encounter with the flowers and his spontaneous integration in their "community" ("crowd", "host", I. 3-4; "jocund company", I. 16). The same process is later re-enacted in imagination: the succession again of lack and loneliness ("vacant", "solitude", I. 20, 22) and fulfilling integration ("bliss", "with pleasure fills", "dances with", I. 22-24). It seems to be a prerequisite for the functioning of this plot mechanism that it does not (and must not) fully reach the level of self-consciousness, since the process is surreptitiously selfinduced. The speaker later extracts what he first projected onto nature (see the anthropomorphic metaphors), an aptitude for self-cure, in the end almost made explicit: "the inward eye" (i.e. poetic imagination) is defined as the "bliss of solitude". The protagonist is also the autodiegetic narrator of the poem. He tells his own story and he does so retrospectively (in the past tense, in I. 1-18). The temporal shift from the concrete past experience to its present imaginative recreation is, as argued above, eventful inasmuch as the experience then becomes repeatable, ultimately (and inadvertently, or so it seems) realised in the verbal medium of the present poetic text itself. The temporal succession of story and narration implied here, i.e. the retrospectivity of the narrative act, may be considered the normal case in narrative fiction. What is unusual, however, and typical for poetry, is that the eventful result of the imagination is recounted in a kind of permanent (because iterative) present. It is here that the function of narrating becomes apparent. The speaker effectively utilises the plot he narrates to define his identity, namely as someone capable of imagination and - by implication - of poetic 
creation. In other words, he identifies himself as a poet through the self-attribution of a story of imaginative creation.

Philip Larkin's “I Remember, I Remember" presents a much more complex form of plotting and retrospective narration:

\section{I remember, I remember}

1 Coming up England by a different line

2 For once, early in the cold new year,

3 We stopped, and, watching men with number plates

4 Sprint down the platform to familiar gates,

5 'Why, Coventry!' I exclaimed. 'I was born here.'

6 I leant far out, and squinnied for a sign

7 That this was still the town that had been 'mine'

8 So long, but found I wasn't even clear

9 Which side was which. From where those cycle-crates

10 Were standing, had we annually departed

11 For all those family hols? ... A whistle went:

12 Things moved. I sat back, staring at my boots.

13 'Was that,' my friend smiled, 'where you "have your roots"?'

14 No, only where my childhood was unspent,

15 I wanted to retort, just where I started:

16 By now l've got the whole place clearly charted.

17 Our garden, first: where I did not invent

18 Blinding theologies of flowers and fruits,

19 And wasn't spoken to by an old hat.

20 And here we have that splendid family

23 I never ran to when I got depressed,

24 The boys all biceps and the girls all chest,

25 Their comic Ford, their farm where I could be

26 'Really myself'. I'll show you, come to that,

27 The bracken where I never trembling sat,

28 Determined to go through with it; where she

29 Lay back, and 'all became a burning mist'.

30 And, in those offices, my doggerel

31 Was not set up in blunt ten-point, nor read

32 By a distinguished cousin of the mayor,

33 Who didn't call and tell my father There

34 Before us, had we the gift to see ahead -

35 'You look as though you wished the place in Hell,'

36 My friend said, 'judging from your face.' 'Oh well, 


\section{I suppose it's not the place's fault,' I said.}

38 'Nothing, like something, happens anywhere.'

(Thwaite, 1988:81-82.)

The poem combines two narrative sequences, both rendered retrospectively: a train journey, which is interrupted by an unexpected stop at the speaker's hometown, Coventry, and the story of the speaker's childhood and adolescence. The train-journey functions as the setting for the life-story, the temporary stop at this particular place triggering memories of the life lived there. Both narratives are concerned with the relevance of place for story. Frame and script for the train journey (public transport and movement from one town to another, respectively) stress the impermanent, accidental, impersonal and fragmentary quality of place in the modern world, as is accentuated by the heterogeneous perception of the station (I. 112) as well as by the fact that this is an in-between stop and the two significant points of the script, the places of departure and arrival, are not mentioned at all. Within this context the final line can be read as a concise summary of such experience, which does not establish any kind of event or closure for this narrative sequence.

Both the speaker and his friend provide an impetus against the apparent insignificance of place, by suggesting the possibility of, and desire for, a special personal relationship, if only in the uncertain form of a search for a relevant sign ("That this was still the town that had been "mine"', I. 7) or a question ("Was that [...] where you "have your roots"?'”, I. 13), in both cases quoted (in inverted commas) as a traditional notion no longer fully believed in. The friend's question triggers the second narrative sequence, which consists of the speaker's personal life-story linked to this place (I. 14-32). Frame and script for this sequence can be identified, respectively, as the general schemata childhood memories and the process of growing-up. However, the term roots and the title of the poem signal more specific concepts for the script of this story. While the plant metaphor suggests "rootedness" in place and organic teleological growth, the allusion to Thomas Hood's "I Remember, I Remember" of 1827 implies a nostalgic image of childhood as paradise and harmonious integration in the environment (which that poem recollects as increasingly lost in the subsequent process of growing-up). The story of childhood and growing-up which the speaker then narrates radically and ironically deviates from these patterns. What he tells is a tale of what did not happen, a sequence of non-incidents, the negative narration of a teleological development. In addition, the sequence again highly ironically activates a more particular pattern only to negate it, 
that of the typical growth of a poet: from the creative child's imaginative animation of his environment ("blinding theologies of flowers and fruits", "spoken to by an old hat", I. 18-19) via his acceptance by sympathetic neighbours and his first love to the final recognition of his poetic gift ("my doggerel", I. 28) not by his family, but by a leading member of the community.

The function of this unusual "negative" form of retrospective narration is determined by its specific integration into the overall retrospective narrative of the train journey. It is significant that the speaker responds to his friend's question about his "roots" with a merely internal, silent negative narrative of his childhood experiences (I. 1415), which he does not communicate, but whose sarcastic emotional colouring is involuntarily betrayed in his face (I. 33-34). A negative narration of a story is different from no narration at all. Although refusing to impart what actually happened, it does provide a structure of sorts, indicating what might have happened in childhood, but did not. This reversal of the script - instead of longing for the lost paradise of childhood (as in Hood) associating it with hell - is already eventful in itself. The conclusion drawn from the narrative - "Nothing, like something, happens anywhere" (I. 36) - adds another aspect to this negative story, namely the sudden insight into the general condition of modern placelessness. The arbritary, insignificant and inconclusive quality of place, characteristic of the overall train journey sequence, is now extended to the speaker's own life story with a vengeance (which was originally started off by a residual expectation of rootedness). The function of this ironic negative story is twofold. Primarily, the recapitulation of his childhood and adolescence in the grotesque terms of what did not happen results in a kind of retrospective self-clarification, especially in the succinct paradoxical formulation of the governing principle abstracted from it. Moreover, this negative plot functions as a characteristically Larkinian form of ironic self-identification, both as person and poet. In comparison with Wordsworth, this self-definition, self-addressed and therefore restricted to the speaker's internal consciousness, is marked by isolation, internal discrepancy and the conspicuous absence of spontaneous joy; and his role as a poet is heavily ironised.12

12 Interestingly, Larkin does surreptitiously stress the highly artistical structure of this poem and thereby contradict the crude ironic self-description as a doggerel poet, e.g. in the very intricate and complicated rhyme pattern, which is based on the repetition and permutation of triple configurations, arranged into four groups of nine lines, not coordinated with the stanzaic divisions. 
Retrospective presentations of plot frequently occur in poems, though by no means occupying the standard position it has in narrative prose fiction. The function often is negotiating a critical transition or self-clarification, as in George Herbert's "Love (III)", John Keats's "On first looking into Chapman's Homer" or Thomas Hardy's "The darkling thrush".

\subsection{Story events: simultaneous narration}

If retrospectivity is usually considered the prototypical temporal relation of the narrative act to the story (in prose fiction as well as in everyday life), simultaneity can be called a particularly widespread constellation of narration in poetry. (For a discussion of this odd and in prose fiction relatively rare narrative device, cf. Cohn, 1993.) The speaker narrates incidents as they occur, enacting or perceiving the story and at the same time communicating it.

Robert Browning's "Meeting at night" provides a simple example, which is complicated, however, by the addition of the companion piece "Parting at morning" with its reversal of the temporal relation story-narration.

\section{Meeting at night}

1 The gray sea and the long black land;

2 And the yellow half-moon large and low;

3 And the startled little waves that leap

4 In fiery ringlets from their sleep,

5 As I gain the cove with pushing prow,

6 And quench its speed i' the slushy sand.

7 Then a mile of warm sea-scented beach;

8 Three fields to cross till a farm appears;

9 A tap at the pane, the quick sharp scratch

10 And blue spurt of a lighted match,

11 And a voice less loud, through its joys and fears,

12 Than the two hearts beating each to each!

(Pettigrew, 1981:451.)

The text emphasises the mere (chronological) succession of incidents and acts by being entirely made up of nouns or noun phrases connected by syndetic particles ("and", "then"). The phrases suggest secret, possibly forbidden love (see "fears", I. 11) as the thematic frame and, as script, the stealthy nightly trip to a tryst with the beloved at a remote secluded place. The narrative sequence thus comprises the speaker-lover's movement across bay and land up to the actual moment of passionately embracing the beloved ("the two 
hearts beating each to each", I. 12). The movement across the dividing space between the lovers is given clear sexual overtones (to be described as isotopies) in phrases such as "fiery", "pushing prow", "quench", "warm", "quick sharp scratch", "blue spurt" (I. 4-10), which inform the sequence with the dynamic progression from desire to gratification. Though this development is in conformity with the conventional sequence pattern and does not markedly deviate from the expected, the final achievement of fulfilled love is endowed with an increased degree of eventfulness by the emphasis on the latent passionate urge (mirrored in the breathless concatenation of nouns) and the obstacle (in terms of space and social or moral norms) to be overcome, by the tension between joys and fears (l. 11).

The act of narration, as the immediate, purely mental reflection accompanying the on-going experience, is simultaneous with the incidents and the final event. Likewise, the focalisation is simultaneous and strictly limited to the respective moment, without any references to the past or the future. The perceptual focus is entirely directed towards the present outward scene, with only one pronominal reference to the speaker (I. 5). At the same time, this concentration on the outward scene is profoundly suffused by the internal passionate desire, which manifests itself in the pervasive sexualisation of the perception. The plot thus signals almost total immersion in the sensuous and sensual experience of present passion and love, screening out all other spatial and temporal dimensions as well as all social concerns. The function of narration is performative: leading to, and concentrating on, the aim of the consummation of love and the union of the two lovers, without, however, completely effacing their separate selves.

This plot and its simultaneous narration are retrospectively thrown into relief and highlighted in their particularity by the plot reversal in the companion piece "Parting at morning".

\section{Parting at morning}

1 Round the cape of a sudden came the sea,

2 And the sun looked over the mountain's rim:

3 And straight was a path of gold for him,

4 And the need of a world of men for me.

(Pettigrew, 1981:452.)

Both direction and thematic content of the plot are reversed. The boat now moves into the open and into the light, away from the night and their secret meeting place. The ultimate aim is no longer the 
gratification of desire in a union of two hearts, but the speaker's own separate individual self, significantly asserted by the closing word of the whole poem ("me") and paralleled with the sun's "straight [...] path of gold", thereby declaring worldly social success and profit his ultimate aim. The focus is opened wide, comprising the sea and the social "world of men", as against the exclusive concentration on the private and secluded during the night. This is a specifically male plot of ambition, achievement and self-assertion in the world. It differs from the secret love plot of "Meeting at night" in two further respects: the development has not yet reached its decisive turning point, its event, and it is narrated retrospectively.

It is not enough, however, merely to state the complete opposition between the plots of the two poems. In a final move one has to construe these two plots as successive phases in one overarching plot (based on the continuity of the figure of the narrator-protagonist). This constellation considerably complicates the plot structure redefining and increasing its eventfulness. The decisive turning point can now be seen to occur in the gap between the two poems constituted by a frame shift from the romantic plot of secret love to the individualist plot of ambition and self-assertion, from a private to a public orientation of the life story. The change from simultaneous to retrospective narration in the two phases of this plot helps define the plot development also in terms of perspective and personal attitude from total emotional involvement and fixation to cognitive (and temporal) detachment. This frame shift is ultimately ambivalent - to be criticised as a severe violation of the romantic love concept, tantamount to betrayal and desertion, or to be praised as an act of liberation and a decision for an open future.

Simultaneous narration or performative presentation of a plot is a very frequent device in poetry with the central function of confronting the readers directly with an ongoing story, drawing them imaginatively into the development and at the same time allowing them to observe the mechanism at work. To mention a few examples from different periods: John Donne's "The sun rising", Thomas Gray's "Elegy written in a country churchyard", P.B. Shelley's "The cloud" or T.S. Eliot's "The love song of J. Alfred Prufrock".

\subsection{Story events: prospective narration}

Tennyson's late poem "Crossing the bar" narrates a story which functions both on a literal and on a metaphorical level: the nightly departure of a ship for a longer voyage as a metaphor for dying. 


\section{Crossing the bar}

1 Sunset and evening star,

2 And one clear call for me!

3 And may there be no moaning of the bar,

4 When I put out to sea,

5 But such a tide as moving seems asleep,

6 Too full for sound and foam,

7 When that which drew from out the boundless deep

8 Turns again home.

9 Twilight and evening bell,

10 And after that the dark!

11 And may there be no sadness of farewell,

12 When I embark;

13 For though from out our bourne of Time and Place

14 The flood may bear me far,

15 I hope to see my Pilot face to face

16 When I have crost the bar.

(Ricks, 1969:1458-1459.)

On the literal level, the poem activates the frame of sea travel and the script of the procedure of an ocean liner leaving the harbour at night and negotiating the dangerous sandbank ("bar") across the harbour entrance before safely gaining the open sea. This concrete level is activated throughout the text by "sunset", "evening star", "put out to sea", "evening bell", et cetera, but also by the phrases "moaning of the bar" and "sound and foam" $(I .3,6)$, which refer to the dangerously whirling shallow waters above the bar at low tide. At the same time another thematic frame, death, is called up by the pervasive isotopy (the semantic implication) of dying in a number of expressions, directly in phrases like "one clear call for me" (I. 2) and "from out our bourne of Time and Place" (I. 13), 13 metaphorically in the references to sunset, night, dark, evening bell and the "sadness of farewell" (I. 11). Correspondingly, the concrete script of the nightly departure for a sea voyage metaphorically signals the script of approaching death (alluding to crossing water as a familiar image for the passage of the dead to Hades in Greek mythology). These two scripts constitute events in different degrees. While the bar is only a relatively minor obstacle for a ship sailing into the open sea, for a

13 The word bourne alludes to Hamlet: "death, / The undiscovered country from whose bourn / No traveller returns" (III, i:78-80; Jenkins, 1982:279). 
human individual "crossing the bar" causes a fundamental crisis loss of one's existence and change into something completely different, possibly into nothing, a transition connected with extreme anxieties and fears. This difference in degree of eventfulness becomes apparent in the different significance of the pilot within the two scripts. The hope to see the pilot after crossing the bar makes less sense within the concrete maritime context than on the metaphorical level of dying and death, where it clearly refers to Christ and the Christian hope of redemption and salvation.

This story is mediated by a combination of simultaneous and prospective narration. The act of narration is situated immediately before the event of crossing the bar. The imminence of the event is emphasised and increased by having the same story told twice (each in two stanzas), with the time advancing from "sunset" (I. 1) to "twilight" (I. 9) and the moment of departure rapidly approaching ("evening bell", I. 9). While the situation prior to departure is rendered simultaneously, with no temporal gap between experience and speaking, as suggested by the exclamations evoking the immediately present situation ("sunset", "evening star", etc.), the actual movement towards and across the bar is narrated prospectively in the form of wishes ("may") and hopes (I.15). Each of the two renderings of the sequence (I. 1-8 and 9-16) singles out the initial and final moments of the prospective narrative by coupling wish or hope with the particular point in time ("when"), anticipating the movement from "when I put out to sea" (I. 4) to "turns again home" (I. 8) and from "when I embark" (I. 12) to "when I have crost the bar" (l. 16). The prospective narration of the decisive, eventful transition has the obvious function of relieving anxiety and re-assuring the agitated mind. Parallel to the increasing imminence of the departure from the first to the second sequence, the quality of re-assurance with respect to the anticipated future state of the speaker is intensified as well: from the impersonal image of turning home (I. 8) to the personal notion of meeting one's guide and saviour ("see my Pilot face to face", I. 15). The speaker reassures himself vis-à-vis the unknown and completely new (see "the dark", I. 10) by re-conceptualising it in terms of the familiar and the known: coming home and directly meeting his personal pilot "face to face" (I. 15). In addition, this consoling prospective narration has a more specifically religious dimension, too. It is a prayer addressed to Christ, to the Pilot to grant a safe and painless passage.

This strategy of coping with the uncertain and often frightening future by prestructuring it through prospective narration can be seen 
in a great number of poems from all epochs. Typically, the act of narration is placed immediately before the decisive event with the attempt to negotiate the further movement narratively. One group of particularly elaborate examples are John Donne's "Valediction poems".

\subsection{Discourse events}

As a rule, plot and event are ultimately located on the story level, though necessarily constituted by the structure of, and the operations on the discourse level in the text (through frames, scripts, selection and organisation of story elements, etc.). There are poems, however, where the decisive change in the plot development (or its anticipation) is essentially shifted to the discourse level, producing what will be called a discourse event. John Keats's "Ode to a nightingale" can serve as a particularly complex example.

\section{Ode to a nightingale}

$\begin{aligned} 1 & \text { My heart aches, and a drowsy numbness pains } \\ 2 & \text { My sense, as though of hemlock I had drunk, } \\ 3 & \text { Or emptied some dull opiate to the drains } \\ 4 & \text { One minute past, and Lethe-wards had sunk. } \\ 5 & \text { 'Tis not through envy of thy happy lot, } \\ 6 & \text { But being too happy in thine happiness, - } \\ 7 & \text { That thou, light-wingèd Dryad of the trees, } \\ 8 & \text { In some melodious plot } \\ 9 & \text { Of beechen green, and shadows numberless, } \\ 10 & \text { Singest of summer in full-throated ease. }\end{aligned}$

II

11 Oh, for a draught of vintage that hath been

12 Cooled a long age in the deep-delvèd earth,

13 Tasting of Flora and the country green,

14 Dance, and Provençal song, and sunburnt mirth!

15 Oh, for a beaker full of the warm South,

16 Full of the true, the blushful Hippocrene,

17 With beaded bubbles winking at the brim,

18 And purple-stainèd mouth,

19 That I might drink, and leave the world unseen,

20 And with thee fade away into the forest dim -

III

21 Fade far away, dissolve, and quite forget

22 What thou among the leaves hast never known,

23 The weariness, the fever, and the fret 
24 Here, where men sit and hear each other groan;

25 Where palsy shakes a few, sad, last gray hairs,

26 Where youth grows pale, and spectre-thin, and dies;

27 Where but to think is to be full of sorrow

28 And leaden-eyed despairs,

29 Where Beauty cannot keep her lustrous eyes,

30 Or new Love pine at them beyond tomorrow.

IV

31 Away! away! For I will fly to thee,

32 Not charioted by Bacchus and his pards,

33 But on the viewless wings of Poesy,

34 Though the dull brain perplexes and retards.

35 Already with thee! Tender is the night,

36 And haply the Queen-Moon is on her throne,

37 Clustered around by all her starry fays;

38 But here there is no light,

39 Save what from heaven is with the breezes blown

40 Through verdurous glooms and winding mossy ways.

$\mathrm{V}$

41 I cannot see what flowers are at my feet,

42 Nor what soft incense hangs upon the boughs,

43 But, in embalmèd darkness, guess each sweet

44 Wherewith the seasonable month endows

45 The grass, the thicket, and the fruit-tree wild -

46 White hawthorn, and the pastoral eglantine;

47 Fast-fading violets covered up in leaves;

48 And mid-May's eldest child,

49 The coming musk-rose, full of dewy wine,

50 The murmurous haunt of flies on summer eves.

$\mathrm{VI}$

51 Darkling, I listen; and, for many a time

52 I have been half in love with easeful Death,

53 Called him soft names in many a musèd rhyme,

54 To take into the air my quiet breath;

55 Now more than ever seems it rich to die,

56 To cease upon the midnight with no pain,

57 While thou art pouring forth thy soul abroad

58 In such an ecstasy.

59 Still wouldst thou sing, and I have ears in vain -

60 To thy high requiem become a sod.

VII

61 Thou wast not born for death, immortal bird!

62 No hungry generations tread thee down;

63 The voice I hear this passing night was heard 
64 In ancient days by emperor and clown:

65 Perhaps the self-same song that found a path

66 Through the sad heart of Ruth, when, sick for home,

67 She stood in tears amid the alien corn;

68 The same that oft-times hath

69 Charmed magic casements, opening on the foam

70 Of perilous seas, in fairy lands forlorn.

VIII

71 Forlorn! The very word is like a bell

72 To toll me back from thee to my sole self!

73 Adieu! The fancy cannot cheat so well

74 As she is famed to do, deceiving elf.

75 Adieu! adieu! Thy plaintive anthem fades

76 Past the near meadows, over the still stream,

77 Up the hill-side; and now 'tis buried deep

78 In the next valley-glades:

79 Was it a vision, or a waking dream?

80 Fled is that music ... Do I wake or sleep?

(Allott, 1975:523-532.)

The existents and incidents of the poem comprise the nightingale, its song and its movement within the landscape on the one hand and the speaker, his acute awareness of human infirmity and mortality, his longing for an ideal immortal existence, on the other. These elements on the story level are transformed into a coherent sequence by activating the following schemata. The frame can be determined as the creative imaginative capacity of the mind for transcending the world of human transitoriness and suffering, specifically associated with the poetological concept of imagination developed in Romanticism. The script is then identifiable as the process of the mind transporting itself into the transcendent world of ideal nature through the power of imagination, particularly through poetry, as indicated by phrases like "Hippocrene" (I. 16) and "on the viewless wings of Poesy" (I. 33). The transcendent ideal quality of this world is constituted by the pervasive isotopies of the mythic (the classical Mediterranean world) and the fantastic in such words as "Dryad" (I. 7), "Flora" (I. 13), "Provençal" (I. 14), "warm South" (I. 15), et cetera.

With the help of these schemata the central narrative sequence of the ode can be constructed: the process of imaginatively entering the ideal world of the nightingale from the initial desire (I. $1 \mathrm{ff}$., esp. I. 6) and the impulse of self-stimulation (l. $11 \mathrm{ff}$.) through the momentary realisation of the imagination (I. $35 \mathrm{ff}$.) to its final collapse (I. $71 \mathrm{ff}$.) and the subsequent reflection on this experience (I. $79 \mathrm{ff}$.). Into this overall sequence two short narrative segments are inserted, 
which contrast the immortal happiness of the nightingale's existence with the experience of human misery and suffering, the first ascribed to mortal humanity as the collective protagonist ("men", in I. 23-30), the second to various historical literary figures as single protagonists (e.g. "Ruth", I. 63-70). The overall sequence is constituted in opposition to the two shorter ones. Whereas the first one provides the psychological motive and impetus for entering the imaginative realm, the second predates and signals the return to the world of the mortals. Finally, the last stanza reflects on the relation between the overall and the two shorter sequences, especially on the reality status of the imaginative narrative (real vs. unreal). The speaker feels unable, however, to decide this question - both with respect to his past imagination ("vision" vs. "waking dream") and to his present state of mind ("wake" vs. "sleep").

As for the function of narrating, the speaker tries to dissociate himself from the two shorter sequences by telling - and ascribing to himself - the central narrative and thereby redefining his status in terms of a preferential affiliation with the ideal intransient world of imagination. His oppositional attitudes to these narratives show in the use of pronouns. The first-person pronoun is only used for the overall sequence, not for the two short ones. The longing for the world of the nightingale and its pervasive contrast with the human condition is accentuated by explicitly addressing the narrative to the nightingale as the narratee (and representative of the ideal existence). The final shift from second to third person ("that music", I. 80) parallels and corroborates the termination of the overall sequence of imagination. Moreover, the rise and fall in the development of this central narrative is mirrored in the spatial dimension by the opposition between proximity and distance, the highest achievement of the power of imagination being marked by (imagined) closeness to the bird ("already with thee", I. 35).

In a first approach to the definition of the ode's emplotment, one may locate the event on the story level as the unexpected and sudden fall out of the imaginative world, paradoxically triggered by the very attempt to perpetuate the affiliation to it. At the height of his imaginative achievement the speaker tries to make his presence in this world permanent through the (metaphorical) equation of this presence with dying (I. $51 \mathrm{ff}$.): "Now [...] seems it rich to die, / To cease upon the midnight with no pain" (I. $55 \mathrm{ff}$.). Death is characterised by the same attributes (and isotopies) of painlessness, harmony, timelessness, of mystic union as the existence of the nightingale: "ease" (I. 10/52), "cease" / "fade away" / "dissolve" (I. 20 ff.; 
I. 56), "no pain" (I. 56 vs. I. 22 ff.). However, the reference to his own death inadvertently brings back the awareness of the fundamental difference between the immortal nightingale and mortal humanity and throws him back on his human lot. This sudden awareness initiates a process of reflection which results in the disillusioned selfconsciousness of the forlorn solitary self ("my sole self", I. 72), the disillusionment about the central romantic value of creative imagination and the regret about the failure of imagination to mask human misery ("the fancy cannot cheat so well / As she is famed to do, deceiving elf", I. $73 \mathrm{ff}$.). Seen in this context, the event of the plot of this ode appears to consist in the modern destruction of the romantic re-enchantment of the world through the imaginative poet, its unmasking as illusion and self-deception. The undecided alternatives at the very end of the poem can then be interpreted as the speaker's desperate attempt to reduce the disillusionment through questioning the reliability of his perception and judgement.

Extending the analysis to the dimension of mediacy is apt to open a broader perspective on the particular plot structure of the poem. The two positions of narrator and protagonist are identified both personally and temporally; i.e. the protagonist is also the autodiegetic narrator of the sequence and he presents his (mental) experiences simultaneously, at the same time as they occur, closing the distance between the narrating and experiencing self. This effect of immediacy is further enhanced by the marked emphasis on simultaneous internal focalisation, in its spatial, temporal, but also emotional facets, as is apparent in the deictics ("here", I. 38; "now", I. 55, etc.) as well as in the highly emotionalised references to the nightingale in accordance with the speaker's momentary mood ("melodious plot", I. 8; "thy high requiem", I. 60; "plaintive anthem", I. 75). Thus the poem suggests the spontaneity of narration and the immediacy and authenticity of the narrated through staging the simultaneity of experience, perception and narration. (For a detailed analysis of the strategies of producing the aesthetic illusion of immediacy in poetry, see Wolf, 1998:271-279.)

In a second approach to the analysis of the plotting in the ode this contrived and staged effect of unmediated authenticity in the dimension of mediacy can now be described in its specific function for the dimension of sequentiality. If one relates the authenticity effect on the discourse level to the theme on the story level, i.e. the precarious status of imaginative creativity and the constant threats to its operability posed by disillusioning consciousness, one can interpret the particular organisation of the discourse as the specific solution to 
the problem presented within the story. On the level of the poem as a work of art, the author succeeds in proving the power of imagination whose failure is being narrated and deplored within the overall sequence - if in a partly different respect, not as a permanent entry into the world of the nightingale, but as an imaginative rendering of that very failure. In other words, the "Ode to a nightingale" is a successful imaginative narrative about the failure of imagination. This effect is enabled by the performativity in the mediation of the psychological story, which helps deflect attention from the elaborate artistic constructedness of the poem. One assistant factor supporting the interrelation between these two levels is the frequent use of poetological phrases ("melodious", I. 8; "singest", I. 10; "on the viewless wings of Poesy", I. 33, etc.). These phrases, while not directly self-referential to the poem, but metaphors for the imaginative process enacted within it, signal the continuity of the frame of imagination between the story and discourse levels of the ode and thus motivate their connection in the form of poetic problem and solution.

Since the plot which results in failure on the story level is continued and successfully completed on the discourse level, one can call this a discourse event. The negative story event (disenchantment) is thus superseded by a positive discourse event (imaginative composition). In consequence, the function of the narrative act changes, too. While the speaker identifies himself through his narration as a potential imaginative poet who ultimately fails because of self-reflection, the author proves himself effectively as a successful poet in mediating this failure.14

This argument does not imply, of course, that every successful poem by its very nature necessarily constitutes a discourse event. The artistically perfect organisation of the discourse level in a poem does not normally have a specific function for its narrative setup. This is only the case where the discourse level as such can be seen to continue the story thematically, where, in other words, story and discourse share the same frame and script, as they do in Keats's "Ode to a nightingale". Other romantic poems with a comparable setup come to mind, like Keats's "Ode on a Grecian urn", Wordsworth's sonnet "The world is too much with us", Coleridge's "Kubla Khan" and "Dejection: an ode". However, discourse events can also be produced by different means, e.g. by a sudden change of frame 
or script in the process of mediating the story, as in Shakespeare's "Sonnet 107", where the frame is abruptly redefined - from the friend's praise for his continued friendship and patronage to the speaker's assertion of his own superiority, on account of his immortalising poetic gift, over the friend, or in Yeats's "On woman", where the script for the prospective re-enactment of the speaker's unrequited love story suddenly changes from aiming at a happy ending to an unmodified repetition of the frustrating experience of the past.

\section{Conclusion}

These heuristic narratological analyses yield the following tentative conclusions about the forms and aspects of plotting in lyric poems. First, poems employ a wide variety of forms of narrative and techniques of narration to present and tackle mental or existential problems confronting the speaker. Second, within this narrative setup the concept of (gradable) eventfulness offers a differentiated method of defining the "point" of poems and locating the decisive turning points in their development. Third, one important dimension of variation in the emplotment of poems concerns the temporal position of the act of narration within the mediated story. Frequently, this act is situated immediately before the event intending to negotiate the decisive transition of the plot. Fourth, the relation of narrator to story told is very variable in terms of time and tense (retrospective, simultaneous, prospective) and mode or mood (negative, optative), with concomitant consequences for the function of narration. Fifth, the act of narration frequently has a specifiable function in poems, such as self-clarification, self-identification, overcoming a crisis or negotiating a necessary transition. Sixth, poems can utilise the poetic discourse level to complete (or redefine) the plot of the story level.

\section{List of references}

ALLOTT, M., ed. 1975. The poems of John Keats. London: Longman.

BAL, M. 1981. The laughing mice; or, On focalization. Poetics today, 2:41-59.

BAL, M. 1985. Narratology: introduction to the theory of narrative. Toronto: University of Toronto Press.

BREMOND, C. 1973. Logique du récit. Paris: Seuil.

BRUNER, J. 1990. Acts of meaning. Cambridge: Harvard University Press.

BRUNER, J. 1991. The narrative construction of reality. Critical inquiry, 18:1-21.

CHATMAN, S. 1978. Story and discourse: narrative structure in fiction and film. Ithaca: Cornell University Press.

CHATMAN, S. 1990. Coming to terms: rhetoric of narrative in fiction and film. Ithaca: Cornell University Press. 
COHN, D. 1993. "I doze and wake": the deviance of simultaneous narration. (In Foltinek, H., Riehle, W. \& Zacharasiewicz, W., eds. Tales and "their telling difference": zur Theorie und Geschichte der Narrativik. Heidelberg: Winter. p. 9-23.)

CULLER, J. 1975. Structuralist poetics: structuralism, linguistics, and the study of literature. London: Routledge.

CULLER, J. 1981. Story and discourse in the analysis of narrative. (In Culler, J. The pursuit of signs: semiotics, literature, deconstruction. Ithaca: Cornell University Press. p. 169-187.)

DE SELINCOURT, E., ed. 1944. The poetical works of William Wordsworth. Oxford: Clarendon.

FLUDERNIK, M. 1996. Towards a "natural" narratology. London: Routledge.

FLUDERNIK, M. 2001. The establishment of internal focalization in odd pronominal contexts. (In Van Peer, W. \& Chatman, S., eds. New perspectives on narrative perspective. Albany: State University of New York Press. p. 101-113.)

FRIEDMAN, N. 1967. Forms of the plot. (In Stevick, P., ed. The theory of the novel. New York: The Free Press. p. 145-166.)

FRYE, N. 1957. Anatomy of criticism. Princeton: Princeton University Press.

GENETTE, G. 1980. Narrative discourse: an essay in method. Ithaca: Cornell University Press.

GOFFMAN, E. 1974. Frame analysis. New York: Harper.

GREIMAS, A.J. 1966. Sémantique structurale. Paris: Larousse.

GROSSMAN, M. 1998. The story of all things: writing the self in English Renaissance poetry. Durham: Duke University Press.

HERMAN, D. 1997. Scripts, sequences, and stories: elements of a postclassical narratology. PMLA, 112:1046-1059.

HERMAN, D. 2002. Story logic: problems and possibilities of narrative. Lincoln: University of Nebraska Press.

HÜHN, P. 1998. Watching the speaker speak: self-observation and selfintransparency in lyric poetry. (In Jeffreys, M., ed. New definitions of lyric: theory, technology, and culture. New York: Garland. p. 215-244.)

HÜHN, P. 2002. Reading poetry as narrative: towards a narratological analysis of lyric poems. (In Todenhagen, C. \& Thiele, W., eds. Investigations of narrative structures. Frankfurt: Lang. p. 13-27.)

HÜHN, P. \& SCHÖNERT, J. 2002. Zur narratologischen Analyse von Lyrik. Poetica, 34:3-4.

JAHN, M. 1996. Windows of focalization: deconstructing and reconstructing a narratological concept. Style, 30:241-67.

JENKINS, H., ed. 1982. The Arden edition of the works of William Shakespeare: Hamlet. London: Methuen.

KINDT, T. \& MÜLLER, H. 1999. Der "implizite Autor": zur Explikation und Verwendung eines umstrittenen Begriffs. (In Jannidis, F., Hrsg. Rückkehr des Autors: zur Erneuerung eines umstrittenen Begriffs. Tübingen: Niemeyer. S. 273-287.)

KINNEY, C.R. 1992. Strategies of poetic narrative: Chaucer, Spenser, Milton, Eliot. Cambridge: Cambridge University Press.

LOTMAN, J.M. 1972. Die Struktur literarischer Texte. München: Fink.

MARTIN, W. 1986. Recent theories of narrative. Ithaca: Cornell University Press. 
MARTINEZ, M. \& SCHEFFEL, M. 1999. Einführung in die Erzählliteratur. München: Beck.

MÜLLER-ZETTELMANN, E. 2000. Lyrik und Metalyrik: Theorie einer Gattung und ihrer Selbstbespiegelung an Hand von Beispielen aus der englischund deutsch-sprachigen Dichtkunst. Heidelberg: Winter.

MÜLLER-ZETTELMANN, E. 2002. Lyrik und Narratologie. (In Nünning, V. \& Nünning, A., Reds. Erzähltheorie transgenerisch, intermedial, interdisziplinär. Trier: Wissenschaftlicher Verlag Trier. S. 129-153.)

NÜNNING, A. 1993. Renaissance eines anthropomorphisierten Passepartouts oder Nachruf auf ein literaturkritisches Phantom? Überlegungen und Alternativen zum Konzept des implied author. Deutsche Vierteljahrsschrift für Literaturwissenschaft und Geistesgeschichte, 67:1-25.

NÜNNING, A. 1999. Unreliable, compared to what? Towards a cognitive theory of unreliable narration: prolegomena and hypotheses (In Grünzweig, W. \& Solbach, A., Reds. Grenzüberschreitungen: Narratologie in Kontext/ Transcending boundaries: narratology in context. Tübingen: Narr. p. 5373.)

NÜNNING, A. 2001. Mimesis des Erzählens: Prolegomena zu einer Wirkungsästhetik, Typologie und Funktionsgeschichte des Akts des Erzählens und der Metanarration. (In Helbig, J., Red. Erzählen und Erzähltheorie im 20. Jahrhundert: Festschrift für Wilhelm Füger. Heidelberg: Winter. S. 13-47.)

PETTIGREW, J., ed. 1981. Robert Browning: the poems. Harmondsworth: Penguin.

PROPP, V. 1968. Morphology of the folktale. Austin: University of Texas Press.

RICKS, C., ed. 1969. The poems of Tennyson. London: Longman.

RIMMON-KENAN, S. 2002. Narrative fiction: contemporary poetics. London: Routledge.

RONEN, R. 1990. Paradigm shift in plot models: an outline of the history of narratology. Poetics today, 11:817-842.

RYAN, M. 1991. Possible worlds, artificial intelligence and narrative theory. Bloomington: Indiana University Press.

SCHMID, W. 1982. Die narrativen Ebenen "Geschehen", "Geschichte", "Erzählung" und "Präsentation der Erzählung". Wiener Slawischer Almanach, 9:83-110.

SEMINO, E. 1995. Schema theory and the analysis of text worlds in poetry. Language and literature, 4(2):79-108.

STANZEL, F. 1979. Theorie des Erzählens. Göttingen: Vandenhoeck \& Ruprecht.

STILLINGER, J. 1985. The plots of romantic poetry. College literature, 12:97112.

THWAITE, A., ed. 1988. Philip Larkin: collected poems. London: Faber.

TODOROV, T. 1966. Les catégories du récit littéraire. Communications, 8:125151.

TOMAŠEVSKIJ, B. 1965. Thematics. (In Lemon, L.T. \& Reis, M.J., eds. Russian formalist criticism: four essays. Lincoln: University of Nebraska Press. p. 61-95.)

WARNING, R. 1997. Interpretation, Analyse, Lektüre: methodologische Erwägungen zum Umgang mit lyrischen Texten. (In Warning, R. Lektüren romantischer Lyrik: von den Trobadors zum Surrealismus. Freiburg: Rombach. S. 9-43.) 
WESTSTEIJN, W.G. 1989. Plot structure in lyric poetry: an analysis of three exile poems by Alexandr Puškin. Russian literature, 26:509-522.

WOLF, W. 1998. Aesthetic illusion in lyric poetry. Poetica, 30:251-289.

WOLF, W. 2002. Das Problem der Narrativität in Literatur, bildender Kunst und Musik: ein Beitrag zu einer intermedialen Erzähltheorie. (In Nünning, V. \& Nünning, A. Reds. Erzähltheorie transgenerisch, intermedial, interdisziplinär. Trier: Wissenschaftlicher Verlag Trier. S. 23-104.)

\section{Key concepts:}

mediacy in poetry

narratological approach to poetry

narratology

poetic plot

poetic sequentiality

representation in poetry

\section{Kernbegrippe:}

mediëring in die poësie

narratologie

narratologiese benadering tot poësie

poëtiese intrige

poëtiese opeenvolging

poëtiese reeksmatigheid

representasie in die poësie 
